\title{
Pemanfaatan Kulit Singkong Sebagai Bahan Baku Karbon Aktif
}

\author{
Landiana Etni Laos, Arkilaus Selan \\ Prodi Pendidikan Fisika STKIP Soe, Nusa Tenggara Timur \\ E-mail:etni.laos@yahoo.com
}

\begin{abstract}
Abstrak. Karbon aktif merupakan produk dari proses aktivasi karbon yang kemampuan penyerapannya lebih tinggi dan memiliki kegunaan lebih banyak daripada karbon biasa. Karbon aktif dapat mengadsorpsi gas dan senyawa-senyawa kimia tertentu atau sifat adsorpsinya selektif, tergantung pada besar atau volume pori-pori dan luas permukaan. Karbon aktif dapat dibuat dari karbon kulit singkong dengan cara dikarbonisasi untuk menghasilkan karbon pada suhu $200^{\circ} \mathrm{C}$, $300^{\circ} \mathrm{C}, 400^{\circ} \mathrm{C}, 500^{\circ} \mathrm{C}$, dan $600^{\circ} \mathrm{C}$. Selanjutnya karbon diaktivasi secara kimia dengan larutan asam fosfat. Proses aktivasi kimia karbon kulit singkong dilakukan dengan merendam karbon kulit singkong dalam larutan $\mathrm{H}_{3} \mathrm{PO}_{4} \quad 2,5 \%$ selama 24 jam. Karbon aktif yang dihasilkan memenuhi standar (SNI) 06-3730-1995 dengan hasil pengujian kadar air antara 4,5\% - 13\% dimana standar SNI maksimum 15\% dan kadar abu antara 1,5\%-7,5\% dimana standar SNI maksimum 10\%, dan dan daya serap iodium antara 2.533,78 mg/g - 2.537,71mg/g dimana standar SNI maksimum $750 \mathrm{mg} / \mathrm{g}$.
\end{abstract}

Kata Kunci: kulit singkong, karbonisasi, aktivasi, karbon aktif

\section{PENDAHULUAN}

Tanaman singkong banyak di temukan di daerah kabupaten Timor Tengah Selatan, yang memiliki banyak manfaat yakni daun singkong dapat digunakan sebagai sayuran, umbinya sebagai bahan makanan tambahan dan masih banyak lagi manfaatnya, Sedangkan kulit singkong belum dimanfaatkan secara maksimal oleh masyarakat. Limbah kulit singkong merupakan residu hasil pertanian yang terdapat dalam jumlah melimpah di kabupaten Timor Tengah Selatan. Oleh karena itu, perlu dilakukan suatu upaya untuk mengaktivasi selulosa non reduksi pada biomassa kulit singkong sehingga diperoleh biomassa yang lebih bernilai ekonomis. Selama ini limbah kulit singkong ini belum dimanfaatkan secara maksimal oleh masyarakat, padahal limbah ini bisa dimanfaatkan sebagai bahan baku karbon aktif. Proses pembuatan karbon aktif mencakup dua tahapan utama, yakni proses karbonisasi bahan baku dan proses aktivasi.

Karbon aktif merupakan suatu bahan berupa karbon amorf yang sebahagian besar terdiri atas atom karbon bebas dan mempunyai permukaan dalam sehingga mempunyai kemampuan daya serap yang baik. Bahan ini mampu mengadsorpsi anion, kation dan molekul dalam bentuk senyawa organik dan anorganik, baik berupa larutan maupun gas. Karbon aktif dapat dibedakan dari karbon berdasarkan sifat pada permukaannya. Permukaan pada karbon masih ditutupi oleh deposit hidrokarbon yang dapat menghambat keaktifannya, sedangkan pada arang aktif permukaannya relatif telah bebas dari deposit sehingga mampu mengabsorpsi karena permukaannya luas dan pori-porinya telah terbuka.

Karbon aktif dapat mengadsorpsi gas dan senyawa-senyawa kimia tertentu atau sifat adsorpsinya selektif, tergantung pada besar atau volume pori-pori dan luas permukaan. Struktur pori ini erat kaitannya dengan daya serap karbon, dimana semakin banyak pori-pori pada permukaan karbon aktif maka daya adsorpsinya juga semakin meningkat. Dengan demikian kecepatan adsorpsinya akan bertambah.

Daya serap karbon aktif merupakan suatu akumulasi atau terkonsentrasinya komponen di permukaan/antar muka dalam dua fasa. Bila ke dua fasa saling berinteraksi, maka akan terbentuk suatu fasa baru yang berbeda dengan masingmasing fasa sebelumnya. Hal ini disebabkan karena adanya gaya tarik-menarik antar molekul, ion atau atom dalam ke dua fasa tersebut. Gaya tarik-menarik ini dikenal sebagai gaya Van der Walls. Pada kondisi tertentu, atom, ion atau 


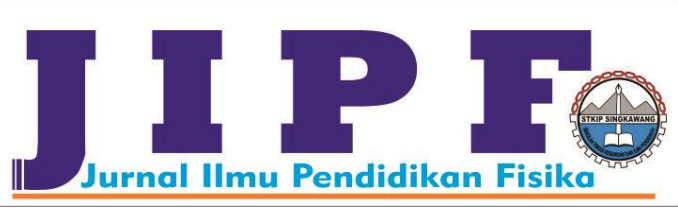

molekul dalam daerah antar muka mengalami ketidak seimbangan gaya.

Faktor-faktor yang mempengaruhi daya serap karbon aktif, yaitu sifat arang aktif, sifat komponen yang diserapnya, sifat larutan dan sistem kontak. Daya serap karbon aktif terhadap komponen-komponen yang berada dalam larutan atau gas disebabkan oleh kondisi permukaan dan struktur porinya. Sifat karbon aktif sendiri selain dipengaruhi oleh jenis bahan baku, luas permukaan, penyebaran pori dan sifat kimia permukaan arang aktif, namun juga dipengaruhi oleh cara aktivasi yang digunakan. Pada tahap aktivasi, terlebih dahulu arang direndam menggunakan bahan pengaktif antara lain $\mathrm{ZnCl}_{2}$, $\mathrm{KOH}, \mathrm{NaCl}, \mathrm{H}_{2} \mathrm{SO}_{4}$ dan $\mathrm{H}_{3} \mathrm{PO}_{4}$, dimana peneliti sebelumnya mengemukakan bahwa $\mathrm{H}_{3} \mathrm{PO}_{4}$ sebagai agen aktivasi akan memberikan hasil terbaik jika dibandingkan dengan $\mathrm{ZnCl}_{2}$ dan $\mathrm{KOH}$. Bahanbahan pengaktif tersebut bersifat sebagai dehidrator yang dapat mereduksi $\mathrm{OH}$ dan $\mathrm{CO}$ yang masih tersisa dari karbon hasil karbonisasi.

Kualitas karbon aktif dapat dinilai berdasarkan persyaratan (SNI) 06-3730-1995 pada Tabel 1 [1].

TABEL 1

STANDAR KUALITAS KARBON AKTIF

\begin{tabular}{lcc}
\hline \multicolumn{1}{c}{ Uraian } & \multicolumn{2}{c}{ Prasyarat kualitas } \\
\cline { 2 - 3 } & Butiran & Serbuk \\
\hline Kadar air \% & Maks. 4,5 & Maks. 15 \\
Kadar abu \% & Maks. 2,5 & Maks. 10 \\
Daya serap terhadap yodium mg/g & Min. 750 & Min. 750 \\
\hline
\end{tabular}

Penelitian ini memiliki tujuan untuk mengetahui kondisi operasi yang paling baik pada suhu karbonisasi serta proses aktivasi pembuatan karbon aktif dari kulit singkong sehingga limbah kulit singkong yang menjadi karbon aktif yang bernilai ekonomis.

Dengan berhasilnya penelitian ini, maka diharapkan dapat mendatangkan beberapa manfaat, diantaranya limbah kulit singkong sebagai karbon aktif dapat dijadikan sebagai pendapatan tambahan yang bernilai jual tinggi bagi pengusaha kecil dan menengah sekaligus juga mengurangi limbah industri rumah tangga.
Jurnal Ilmu Pendidikan Fisika

Volum 1 Nomor 1 Maret 2016. Halaman 32-36 p-ISSN: 2477-5959 e-ISSN: 2477-8451

\section{METODE}

Alat yang digunakan dalam penelitian ini adalah furnance, oven, tanur, lumpang porselen, pipet tetes, batang pengaduk, erlenmeyer, labu ukur, neraca analitik, desikator, ayakan ukuran 100 mesh.

Bahan-bahan yang digunakan diantaranya: kulit singkong, $\mathrm{H}_{3} \mathrm{PO}_{4}$, kertas saring, kertas $\mathrm{pH}$ universal, dan aquades.

Preparasi kulit singkong dilakukan dengan cara membersihkan kulit singkong dengan mengupas kulit luar dan dikeringkan dengan cara di jemur. Selanjutnya pembuatan arang kulit singkong dilakukan pada suhu $200^{\circ} \mathrm{C}, 300^{\circ} \mathrm{C}, 400^{\circ} \mathrm{C}, 500^{\circ} \mathrm{C}$, $600^{\circ} \mathrm{C}$.

Proses Aktivasi dilakukan dengan cara kimia yaitu dibuat lima perlakuan dengan masingmasing arang singkong sebanyak 10 gram direndam dalam larutan $\mathrm{H}_{3} \mathrm{PO}_{4}$ dengan variasi konsentrasi 2,\%, 3\%, 4\%, 5\% selama 24 jam. Karbonaktif yang dihasilkan dicuci dengan aquadest sampai filtrat mempunyai $\mathrm{pH}$ netral $(\mathrm{pH}$ 6 sampai 7) yang diukur menggunakan kertas $\mathrm{pH}$ universal kemudian disaring dengan menggunakan kertas saring. Sampel yang diperoleh dikeringkan di dalam oven pada suhu $100^{\circ} \mathrm{C}$ selama 1 jam.

Ada beberapa pengujian yang dilakukan dalam pembuatan karbon aktif, meliputi uji kadar air, uji kadar abu, dan uji daya serap terhadap iodium. Prosedur penetapan kadar air mengacu pada Standar Nasional Indonesia (SNI) 06-3730-1995 tentang syarat mutu dan pengujian arang aktif. Kadar air ditentukan dengan cara pengeringan di dalam oven. Sebanyak 2 gram karbon aktif ditempatkan di dalam cawan aluminium yang telah diketahui bobotnya, kemudian dikeringkan dalam oven pada suhu $105^{\circ} \mathrm{C}$ hingga bobot konstan. Selanjutnya contoh didinginkan di dalam desikator selama 15 menit sebelum ditimbang beratnya. Kadar air dapat dihitung dengan persamaan berikut:

$$
\% \text { kadar air }=\frac{a-b}{a} \times 100 \%
$$

Dimana: $\quad \mathrm{a}=$ massa awal karbon aktif $(\mathrm{g})$ $\mathrm{b}=$ massa akhir karbon aktif $(\mathrm{g})$ 


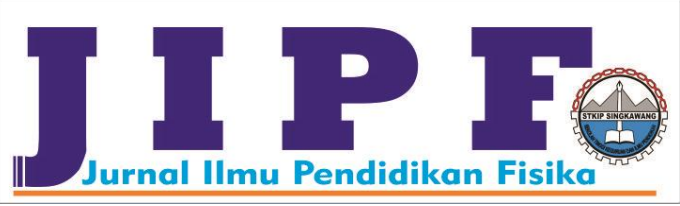

Untuk uji kadar abu, sebanyak 2 gram arang aktif dimasukkan dalam cawan yang telah diketahui bobotnya, kemudian di furnace pada suhu $400^{\circ} \mathrm{C}$ hingga seluruh sampel menjadi abu, kemudian didinginkan dalam desikator hingga suhu konstan lalu ditimbang. Kadar abu karbon dapat dihitung dengan menggunakan rumus sebagai berikut:

$$
\% \text { kadar } a b u=\frac{b}{a} \times 100 \%
$$

$$
\text { Dimana : } \quad \mathrm{a}=\text { massa awal karbon aktif }(\mathrm{g})
$$$$
\mathrm{b}=\text { massa akhir karbon aktif }(\mathrm{g})
$$

Pengujian terhadap daya serap iodium dilakukan dengan menimbang karbon aktif 5 gram dan campurkan dengan $100 \mathrm{ml}$ larutan Iodium 0,1 N. Kocok dengan alat pengocok selama 15 menit. Setelah itu pindahkan ke dalam tabung sentrifugal sampai karbon aktif turun, kemudian mengambil $10 \mathrm{ml}$ cairan itu dan titrasi dengan larutan natrium tiosulfat $0,1 \mathrm{~N}$. Jika warna kuning pada larutan mulai samar, tambahakan larutan amilum $1 \%$ sebagai indikator. Titrasi kembali warna biru tua hingga menjadi warna bening. Rumus perhitungan daya serap Iodium yaitu sebagai berikut:

dayaserapiod $=\frac{A \frac{B \times N\left(\mathrm{Na}_{2} \mathrm{~S}_{2} \mathrm{O}_{3}\right)}{N(\text { iodin })} 126,93 f p}{\alpha}$

Dimana :

$$
\begin{array}{lll}
A & = & \text { Volume larutan iodin }(\mathrm{mL}) \\
B & = & \text { Volume } \mathrm{Na}_{2} \mathrm{~S}_{2} \mathrm{O} \text { yang terpakai } \\
& (\mathrm{mL}) \\
= & \text { faktor pengenceran } \\
f p & \text { bobot karbon aktif }(\mathrm{g}) \\
\alpha & =\text { kosentrasi } \mathrm{Na}_{2} \mathrm{~S}_{2} \mathrm{O}_{3}(\mathrm{~N}) \\
\mathrm{N}\left(\mathrm{Na}_{2} \mathrm{~S}_{2} \mathrm{O}_{3}\right) & =\text { kosentrasi iodin }(\mathrm{N}) \\
\mathrm{N}(\text { iodin }) & = \\
126,93 & \text { jumlah iodin sesuai } 1 \mathrm{~mL} \text { larutan } \\
& \mathrm{Na}_{2} \mathrm{~S}_{2} \mathrm{O}_{3}
\end{array}
$$

\section{HASIL DAN PEMBAHASAN}

Dari penelitian yang telah dilakukan diperoleh hasil sebagai berikut:
Jurnal Ilmu Pendidikan Fisika

Volum 1 Nomor 1 Maret 2016. Halaman 32-36 p-ISSN: 2477-5959 e-ISSN: 2477-8451

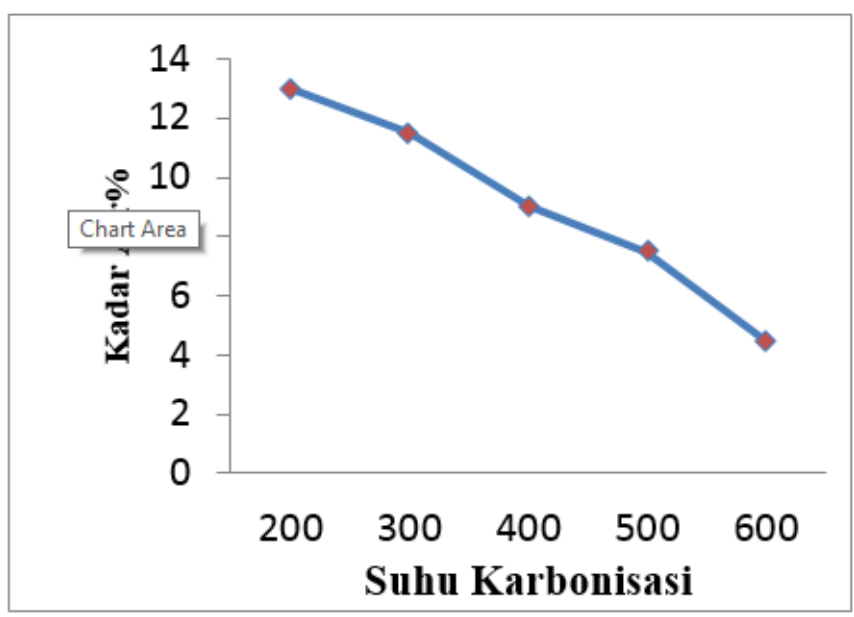

Gambar. 1 Pengujian kadar air (hubungan antara suhu karbonisasi dengan kadar air)

Pada gambar tersebut diketahui bahwa kadar air karbon aktif maksimal terdapat pada suhu $200^{\circ} \mathrm{C}$ yaitu sebesar $13 \%$. Sedangkan kadar air minimal terdapat pada karbon aktif dengan suhu $600^{\circ} \mathrm{C}$ yaitu sebesar $4,5 \%$. Hal ini menunjukkan kualitas karbon aktif yang dihasilkan dalam penelitian ini cukup baik. Kadar air yang terkandung sesuai persyaratan menurut Standar Nasional Indonesia (SNI) 06-3703-1995 yaitu maksimum 15\% [1].

Perhitungan kadar air bertujuan mengetahui sifat higroskopis dari karbon aktif, dimana umumnya karbon aktif memiliki sifat afinitas yang sangat besar terhadap air. Sifat yang sangat higrokopis inilah yang mengakibatkan karbon aktif digunakan sebagai absorben. Temperatur dan lamanya waktu karbonisasi memberikan pengaruh yang signifikan terhadap kadar air yang bisa diserap. Kadar air semakin menurun dengan kenaikan temperatur dan lamanya waktu karbonisasi.

Terikatnya molekul air yang ada pada karbon aktif oleh aktivator menyebabkan pori-pori pada karbon aktif semakin besar. Semakin besar poripori maka luas permukaan karbon aktif semakin bertambah. Hal ini mengakibatkan meningkatnya kemampuan adsorpsi dari karbon aktif.

Kadar abu merupakan banyaknya kandungan oksida logam yang terdiri dari mineral-mineral dalam suatu bahan yang tidak dapat menguap pada proses pengabuan. 

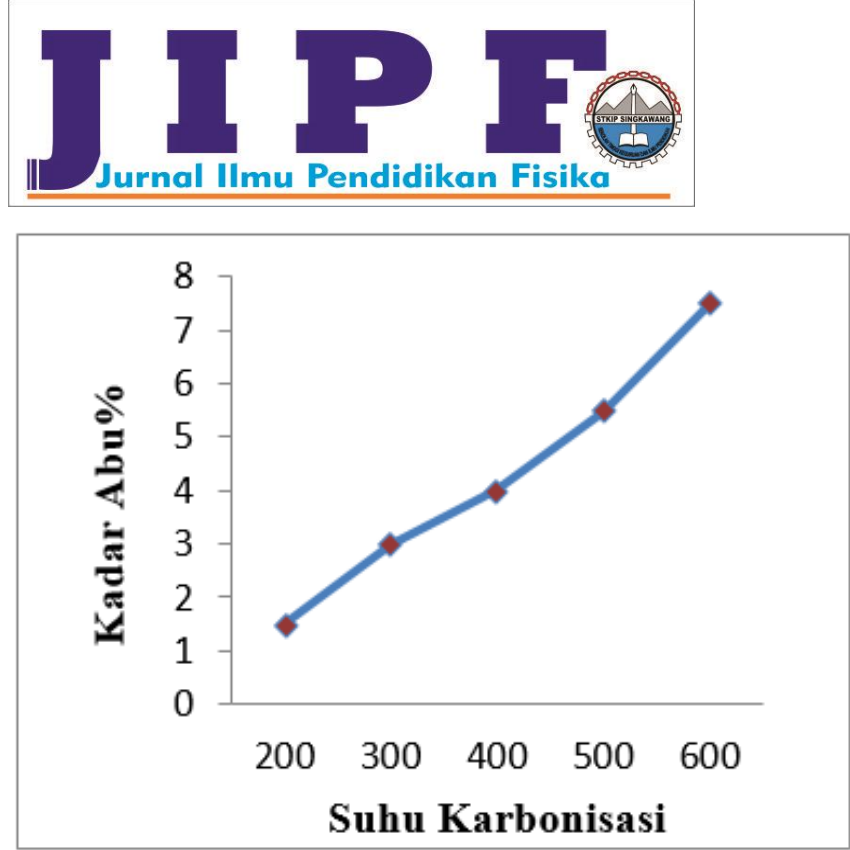

Gambar. 2 Pengujian kadar abu (hubungan antara suhu karbonisasi dengan kadar abu)

Kadar abu sangat berpengaruh terhadap kualitas barbon aktif. Keberadaan abu yang berlebihan dapat menyebabkan terjadinya penyumbatan poripori karbon aktif, sehingga luas permukaan karbon aktif menjadi berkurang. Dari gragfik di atas dapat dilihat bahwa semakin tinggi suhu karbonisasi, maka kadar abu semakin meningkat. Peningkatan ini disebabkan oleh kenaikan suhu karbonisasi yang memicu teroksidasinya sebagian besar zat volatil termasuk pula karbon. Sedangkan abu tidak ikut teroksidasi karena bukan merupakan zat volatil. Semakin meningkatnya kadar abu pada karbon aktif dengan penambahan bahan kimia maka akan terjadi proses oksidasi lebih lanjut terutama dari partikel halus.

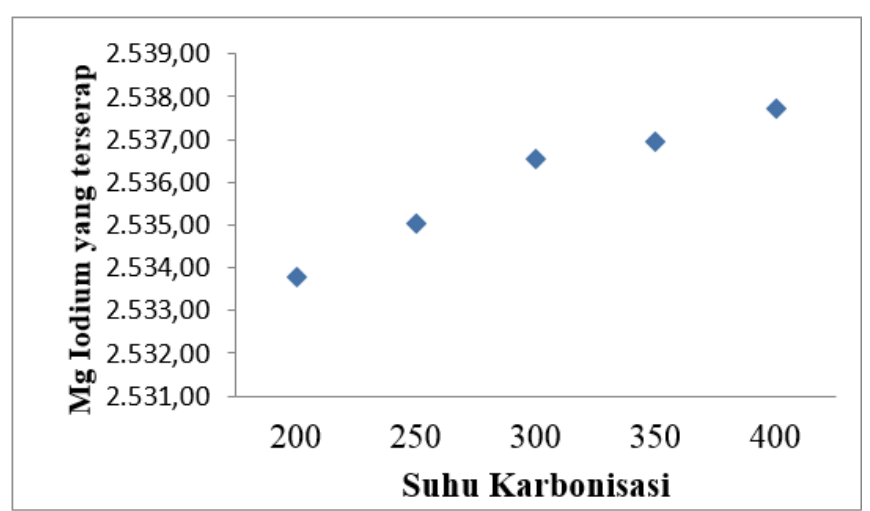

Gambar. 3 Pengujian daya serap iodium (hubungan antara suhu karbonisasi dengan bilangan iodium)

Daya adsorpsi karbon aktif terhadap iod memiliki korelasi dengan luas permukaan dari karbon aktif. Semakin besar angka iod maka semakin besar kemampuannya dalam
Jurnal Ilmu Pendidikan Fisika

Volum 1 Nomor 1 Maret 2016. Halaman 32-36 p-ISSN: 2477-5959 e-ISSN: 2477-8451

mengadsorpsi adsorbat atau zat terlarut. Untuk bilangan Iodin akan semakin bertambah, daya serap terhadap Iod semakin besar dengan kenaikan suhu, ini berarti bahwa kualitas arang aktif akan semakin baik dalam penyerapan. Luas area permukaan pori merupakan suatu parameter yang sangat penting dalam menentukan kualitas dari suatu karbon aktif sebagai adsorben. Hal ini disebabkan karena luas area permukaan pori merupakan salah satu faktor yang mempengaruhi daya adsorpsi dari suatu adsorben.

Kereaktifan dari karbon aktif dapat dilihat dari kemampuannya mengadsorpsi substrat. Daya adsorpsi tersebut dapat ditunjukkan dengan besarnya angka iod yaitu angka yang menunjukkan seberapa besar adsorben dapat mengadsorpsi iod. Semakin besar nilai angka iod maka semakin besar pula daya adsorpsi dari adsorben. Penambahan larutan iod berfungsi sebagai adsorbat yang akan diserap oleh karbon aktif sebagai adsorbennya. Terserapnya larutan iod ditunjukkan dengan adanya pengurangan konsentrasi larutan iod.

Pengukuran konsentrasi iod sisa dapat dilakukan dengan menitrasi larutan iod dengan natrium triosulfat $0,1 \mathrm{~N}$ dan indikator yang digunakan yaitu amilum. Peningkatan bilangan Iod terjadi sebagai akibat semakin banyaknya pengotor yang terlepas dari permukaan karbon aktif. Seiring dengan peningkatan suhu, pengotor-pengotor yang mulanya terdapat pada bagian pori dan menutupi pori, ikut terlepas atau teruapkan sehinggga memperluas permukaan karbon aktif. Semakin besar luas permukaan karbon aktif maka semakin besar kemampuan adsorpsi karbon aktif.

Dari hasil penelitian bilangan iodin karbon aktif meningkat dengan semakin tingginya suhu sintesis. Daya serap iodin karbon aktif maksimal terdapat pada karbon aktif yang dikarbonisasi pada suhu $600^{\circ} \mathrm{C}$ yaitu sebesar $2.537,71 \mathrm{mg} / \mathrm{g}$. Sedangkan daya serap iodin minimal terdapat pada karbon aktif yang dikarbonisasi pada suhu $200^{\circ} \mathrm{C}$ yaitu sebesar $2.533,78 \mathrm{mg} / \mathrm{g}$. Daya serap iodin yang diperoleh pada penelitian ini telah memenuhi SNI 06-3703-1995 yaitu minimal $750 \mathrm{mg} / \mathrm{g}$. 


\section{KESIMPULAN}

Kesimpulan dari penelitian ini adalah karbon aktif dapat diperoleh dari kulit singkong yang di karbonisasi pada suhu $200^{\circ} \mathrm{C}, 300^{\circ} \mathrm{C}, 400^{\circ} \mathrm{C}$, $500^{\circ} \mathrm{C}$, dan $600^{\circ} \mathrm{C}$. Kemudian diaktivasi dengan larutan $\mathrm{H}_{3} \mathrm{PO}_{4} 2,5 \%$ selama 24 jam. Karbon aktif yang dihasilkan memenuhi standar (SNI) 063730-1995 dengan hasil pengujian kadar air antara 4,5\% - 13\% dimana standar SNI maksimum $15 \%$ dan kadar abu antara 1,5\%-7,5\% dimana standar SNI maksimum $10 \%$, dan dan daya serap iodin antara $2.533,78 \mathrm{mg} / \mathrm{g}-2.537,71 \mathrm{mg} / \mathrm{g}$ dimana standar SNI maksimum $750 \mathrm{mg} / \mathrm{g}$.

Adapun saran dalam penelitian ini yakni sebaiknya dilakukan penelitian lebih lanjut dengan menggunakan variasi konsentrasi zat aktivator, dan waktu aktivasi yang berbeda untuk menghasilkan karbon aktif yang lebih baik. Selain itu dapat pula dilakukan penelitian lebih lanjut dengan menggunakan jenis zat aktivator yang berbeda pula misalnya jenis aktivator zat asam ataupun basa.
Jurnal Ilmu Pendidikan Fisika

Volum 1 Nomor 1 Maret 2016. Halaman 32-36 p-ISSN: 2477-5959 e-ISSN: 2477-8451

\section{DAFTAR PUSTAKA}

[1] Anonim, “Mutu dan Cara Uji Arang Aktif Teknis”, Standar Nasional Indonesia (SNI) 06-3730-1995, Dewan Standarisasi Jakarta. Sekretariat Jenderal Kehutanan. Biro Perencanan, Jakarta, 1995.

[2] Anonymous, "Mutu dan Cara Uji Arang Aktif, Standar Industri Indonesia No. 0258-79”, Departemen Perindustrian, 1979.

[3] Budiono, dkk, "Pengaruh aktivasi arang tempurung kelapa dengan asam sulfat dan asam fosfat untuk adsorpsi fenol", Universitas Diponegoro, Yogyakarta. 51-56, 2005.

[4] Deni dan Farid, "Pembuatan Karbon Aktif dari Cangkang Biji Karet", Laporan Penelitian Teknik kimia Universitas Sriwijaya, 2006.

[5] Djatmiko dan Prowiro, "Pembuatan Arang Aktif", Bandung Lembaga Ilmu Pengetahuan Indonesia, 1970.

[6] Gunawan, E. R dan D. Suhendra, "Pembuatan Arang Aktif dari Batang Jagung Menggunakan Aktivator Asam Sulfat dan Penggunaannya pada Penjerapan Ion Tembaga (II)", Makara Sains, 14 (1): 22-26, 2010.

[7] Suherman, dkk, "Pembuatan Karbon Aktif Dari Limbah Kulit Singkong UKM Tapioka Kabupaten Pati”, Seminar Nasional Teknik Kimia Indonesia, Bandung, 2009.

[8] Sembiring, M., dan Sinaga, T., "Arang Aktif”, Jurusan Teknik Industri, Fakultas Teknik, Universitas Sumatera Utara, 2003.

[9] Sarwani, "Pengaruh Jenis Bahan Baku, Suhu, dan Waktu Aktivasi Terhadap Mutu dan Rendemen Karbon Aktif Hasil Aktivasi”, Fakultas Teknologi Pertanian, IPB, Bogor, 1989. 